\title{
Comparison of Ethanol Yield Coefficients Using Saccharomyces cerevisiae, Candida lusitaniae, and Kluyveromyces marxianus Adapted to High Concentrations of Galactose with Gracilaria verrucosa as Substrate
}

\author{
Yurim Park, In Yung Sunwoo, Jiwon Yang, Gwi-Teak Jeong, and Sung-Koo Kim* \\ Department of Biotechnology, Pukyong National University, Busan 48513, Republic of Korea
}

\begin{abstract}
The red seaweed Gracilaria verrucosa has been used for the production of bioethanol. Pretreatment for monosaccharide production was carried out with $12 \%$ (w/v) G. verrucosa slurry and $500 \mathrm{mM} \mathrm{HNO}_{3}$ at $121^{\circ} \mathrm{C}$ for $90 \mathrm{~min}$. Enzymatic hydrolysis was performed with a mixture of commercial enzymes (Cellic C-Tec 2 and Celluclast $1.5 \mathrm{~L} ; 16 \mathrm{U} / \mathrm{ml}$ ) at $50^{\circ} \mathrm{C}$ and $150 \mathrm{rpm}$ for $48 \mathrm{~h}$. G. verrucosa was composed of $66.9 \%$ carbohydrates. In this study, $61.0 \mathrm{~g} / \mathrm{L}$ monosaccharides were obtained from $120.0 \mathrm{~g} \mathrm{dw} / \mathrm{l}$ G. verrucosa. The fermentation inhibitors such as hydroxymethylfurfural (HMF), levulinic acid, and formic acid were produced during pretreatment. Activated carbon was used to remove HMF. Wildtype and adaptively evolved Saccharomyces cerevisiae, Candida lusitaniae, and Kluyveromyces marxianus were used for fermentation to evaluate ethanol production.
\end{abstract}

Keywords: Bioethanol, thermal acid hydrolysis, Gracilaria verrucosa, enzymatic saccharification, adaptive evolution, fermentation

Received: February 11, 2020 Accepted: March 15, 2020

First published online: March 20, 2020

*Corresponding author Phone: +82-51-629-5868 Fax: + 82-51-629-5863 E-mail: skkim@pknu.ac.kr

pISSN 1017-7825 elSSN 1738-8872

Copyright(C) 2020 by The Korean Society for Microbiology and Biotechnology

\section{Introduction}

The burning of fossil fuels increases $\mathrm{CO}_{2}$ levels, contributing to global warming. Fossil fuels are consumed around the world and cause environmental pollution. One of the objectives of the Korean Peninsula Energy Development Organization is the development of hydrogen energy [1]. The goals of energy research are different for each country. The United States has announced the consolidation of the bioethanol industry from 2020 . Research on bioethanol is important for bioenergy production. The use of bioethanol is advantageous because it can mix with other liquid fuels such as gasoline.

The ocean covers more than $70 \%$ of the earth, and the potential of marine resources is expected to be greater than that of land resources. Therefore, marine biomass has been actively investigated for bioethanol production in recent years. Seaweeds are macroalgae that have been used as marine biomass to produce bioethanol. They are a third-generation biofuel source and grow using carbon dioxide, making them environmentally friendly $[1,2]$. Seaweeds are a sustainable non-food resource with rapid biomass growth [22]. Furthermore, seaweeds do not contain lignin; thus, they are easy to hydrolyze. Seaweeds can be classified into the three categories of green, brown, and red seaweeds. In comparison with other types of seaweeds, red seaweeds have a higher sugar content, which contributes to bioethanol production. Therefore, the red seaweed Gracilaria verrucusoa was used in this study [4].

\section{Materials and Methods}

Raw Material

G. verrucosa was obtained from Wando (Jeonnam, Korea). Dried seaweed samples were ground using a hammer mill. The seaweed powder was passed through a 150-mesh sieve before pretreatment [5]. The composition of G. verrucosa was analyzed by the Feed and Foods Nutrition Research Center at Pukyong National University in Busan, Korea.

\section{Thermal Acid Hydrolysis}

Thermal acid hydrolysis conditions for G. verrucosa were optimized by maintaining the temperature at $121^{\circ} \mathrm{C}$ and varying the slurry content $(6.3 \sim 17.7 \%)$, nitric acid $\left(\mathrm{HNO}_{3}\right)$ concentration $(175.8 \sim 824.2 \mathrm{mM})$, and treatment 
time (17.58 102.42 $\mathrm{min})$. The samples were transferred to a cold water bath and allowed to cool to room temperature [6]. The optimal $\mathrm{HNO}_{3}$ concentration was determined based on the acid hydrolysis efficiency $\left(E_{p}\right)$ as defined in Eq. (1):

$$
E_{p}=\frac{\Delta \mathrm{S}_{\mathrm{glu}+\mathrm{gal}}(\mathrm{g} /)}{\mathrm{TC}(\mathrm{g} /)} \times 100(\%)
$$

where $E_{p}$ indicates the efficiency of thermal acid hydrolysis (\%), $\Delta \mathrm{S}_{\text {glu }+ \text { gal }}$ is the increase in galactose and glucose (g/l) concentrations during hydrolysis, and TC is the total carbohydrate content $(\mathrm{g} / \mathrm{l})$ of the biomass $[6,7,9]$. Sugars in G. verrucosa consist mainly of glucose and galactose. Therefore, $\Delta \mathrm{S}_{\text {glu }+ \text { gal }}$ was considered as the total sugar obtained by pretreatment as shown in Eq. (2):

$$
Y=\beta_{0}+\sum_{i=1}^{3} \beta_{i} X_{i}+\sum_{i=1}^{3} \beta_{i i} X_{i}^{2}+\sum_{i=1}^{2} \sum_{j=i+1}^{3} \beta_{i j} X_{i} X_{j}
$$

where $\mathrm{Y}$ is the response factor as sugar yield of $E_{p}, \beta_{0}$ is the intercept term, $\beta_{i}$ is the first-order model coefficient, $\beta_{i i}$ is the quadratic coefficient for factor $i$, and $\beta_{i j}$ is the linear model coefficient for the interaction coefficient between factors $i$ and $j$. The quality of fit for the polynomial model equation was expressed as the coefficient of determination $\left(\mathrm{R}_{2}\right)$. Response surface methodology (RSM) was utilized to optimize the condition of pretreatment with $\mathrm{HNO}_{3}$ and to evaluate the effect of variables including pretreatment temperature $\left(\mathrm{X}_{1}\right), \mathrm{HNO}_{3}$ concentration $\left(\mathrm{X}_{2}\right)$, and reaction time $\left(\mathrm{X}_{3}\right)$ on sugar yield $(\mathrm{Y})$. The slurry was then adjusted to $\mathrm{pH} 5.0$ with $\mathrm{NaOH}$ to measure monosaccharide content by high-performance liquid chromatography (HPLC). All statistical calculations were performed with the response surface methodology (RSM) using SAS software (ver. 9.4; SAS Institute, Cary, NC, USA) as shown in Table 1 [10].

\section{Enzymatic Saccharification}

$\mathrm{NaOH}(10 \mathrm{~N})$ was used to adjust the $\mathrm{pH}$ to 5.0 for enzyme activation [6, 7]. Enzymatic saccharification was conducted by adding 16 units/ml Celluclast 1.5L (854 EGU/ml; Novozymes, Bagsvaerd, Denmark) [6], 16 units/ml Cellic C-Tec2 (120 FPU/ml; Novozymes, Bagsvaerd, Denmark), and a mixture containing a 1:1 ratio of Celluclast 1.5 L and Cellic C-Tec2 (16 units/ml) [8]. Celluclast $1.5 \mathrm{~L}$ contains endoglucanase, and Cellic C-Tec2 is a complex of enzymes. Enzyme kinetics were determined using the Hanes-Woolf equation derived from the MichaelisMenten equation as shown in Eq. (3):

$$
\frac{[S]}{V}=\frac{[S]}{V_{\max }}+\frac{K_{m}}{V_{\max }}
$$

where $[s]$ and $V$ represent the substrate concentration (G. verrucosa) and the reaction rate, respectively. $\mathrm{K}_{\mathrm{m}}$ is a Michaelis-Menten constant and indicates the maximum reaction rate at the substrate.

The amount of monosaccharides obtained from enzymatic saccharification was determined as shown in Eq. (4), and the efficiency was calculated:

$$
E_{s}(\%)=\frac{\Delta \mathrm{S}_{\mathrm{glu}}(\mathrm{g} / \mathrm{l})}{\mathrm{TC}(\mathrm{g} / 1)} \times 100
$$

\begin{tabular}{|c|c|c|c|c|}
\hline \multirow{2}{*}{$\begin{array}{c}\text { Design } \\
\text { point }\end{array}$} & \multicolumn{3}{|c|}{ Independent variable } & \multirow{2}{*}{$\begin{array}{c}\text { Dependent variable } \\
\text { Y } \\
\text { Monosaccharides }(\mathrm{g} / \mathrm{l})\end{array}$} \\
\hline & $\begin{array}{l}\text { Slurry concentration, } \\
\mathrm{X}_{1}(\mathrm{w} / \mathrm{v})\end{array}$ & $\begin{array}{c}\mathrm{HNO}_{3} \text { concentration, } \\
\mathrm{X}_{2}(\mathrm{mM})\end{array}$ & $\begin{array}{l}\text { Thermal hydrolysis time, } \\
\mathrm{X}_{3} \text { (min) }\end{array}$ & \\
\hline 1 & 16 & 700 & 120 & 50.08478 \\
\hline 2 & 16 & 300 & 120 & 35.71804 \\
\hline 3 & 16 & 700 & 60 & 42.11600 \\
\hline 4 & 16 & 700 & 120 & 50.08478 \\
\hline 5 & 8 & 300 & 60 & 17.89879 \\
\hline 6 & 8 & 300 & 120 & 22.63901 \\
\hline 7 & 8 & 700 & 160 & 27.88817 \\
\hline 8 & 8 & 700 & 120 & 30.63901 \\
\hline 9 & 12 & 500 & 90 & 57.45969 \\
\hline 10 & 17.7 & 500 & 90 & 53.34028 \\
\hline 11 & 6.3 & 500 & 90 & 15.53930 \\
\hline 12 & 12 & 824.2 & 90 & 54.27600 \\
\hline 13 & 12 & 175.8 & 90 & 50.94499 \\
\hline 14 & 12 & 500 & 132.42 & 56.18084 \\
\hline 15 & 12 & 500 & 47.58 & 49.33814 \\
\hline 16 & 12 & 500 & 90 & 57.45969 \\
\hline 17 & 12 & 500 & 90 & 57.45969 \\
\hline
\end{tabular}

Table 1. RSM formula to determine optimal pretreatment conditions. 
where $E_{s}$ is the efficiency of enzymatic saccharification, $(\%), \Delta \mathrm{S}_{\mathrm{glu}}$ is the increase in glucose concentration $(\mathrm{g} / \mathrm{L})$ during enzymatic saccharification, and TC is the total carbohydrate content $(\mathrm{g} / \mathrm{l})$ of the biomass. Saccharification was carried out in $100 \mathrm{ml}$ of $12 \%(\mathrm{w} / \mathrm{v})$ seaweed slurry at $50^{\circ} \mathrm{C}$ with $150 \mathrm{rpm}$ shaking for $48 \mathrm{~h}$. Samples were collected for the determination of monosaccharide and hydroxymethylfurfural (HMF) concentrations by HPLC $[12,13]$.

\section{Removal of HMF}

HMF removal after enzyme saccharification was performed using activated carbon powder (Duksan Pure Chemical Co., Ltd., Korea). A shaking incubator was used to remove HMF produced during pretreatment and saccharification. The hydrolysate was treated with $2 \%(\mathrm{w} / \mathrm{v})$ activated carbon (reaction temperature of $50^{\circ} \mathrm{C}$, rotational speed of $150 \mathrm{rpm}$, and reaction time of $2 \mathrm{~min}$ ). The adsorption surface area of the activated carbon powder was $1,400 \sim 1,600 \mathrm{~m}^{2} / \mathrm{g}$. The ethanol fermentation inhibitor was removed, and the samples were centrifuged at $8,000 \times g$ for $20 \mathrm{~min}$ to remove activated carbon. The monosaccharide and residual HMF concentrations in the supernatant were evaluated by HPLC [5], and the HMF removal efficiency was calculated:

$$
E_{R}=\frac{\mathrm{C}_{\mathrm{HMF}}-\mathrm{R}}{\mathrm{C}_{\mathrm{HMF}}} \times 100
$$

where $E_{R}$ is the efficiency of $\mathrm{HMF}$ removal (\%) by activated carbon. $C_{H M F}$ represents the monosaccharides before HMF removal by activated carbon, and $\mathrm{R}$ represents the monosaccharides lost during HMF removal.

\section{Ethanol Fermentation}

Ethanol fermentation was performed with $100 \mathrm{~mL}$ of $12 \%$ (w/v) G. verrucosa hydrolysate in $250 \mathrm{~mL}$ Erlenmeyer flasks. Adaptive evolution to high concentrations of galactose was carried out for $48 \mathrm{~h}$, and yeasts $(1.0 \mathrm{~g} \mathrm{dcw} / \mathrm{l})$ were inoculated into $100 \mathrm{ml}$ of G. verrucosa hydrolysate [5].

Fermentation for ethanol production was performed at $30^{\circ} \mathrm{C}$ and $150 \mathrm{rpm}$ using yeasts that were evolutionarily adapted to galactose and wild-type yeasts with $G$. verrucosa as the substrate.

The ethanol yield coefficient $\left(\mathrm{Y}_{\mathrm{EtOH}}, \mathrm{g} / \mathrm{g}\right.$ ) was defined as the maximum ethanol concentration $(\mathrm{g} / \mathrm{l})$ determined based on the total initial fermentable galactose and glucose concentration at the onset of fermentation $(\mathrm{g} / \mathrm{l})$ as shown in Eq. (6) [13]:

$$
\mathrm{Y}_{E t O H}(\mathrm{~g} / \mathrm{g})=\frac{[\text { EtOH }]_{\max }}{[\text { Monosaccharide }]_{\text {ini }}}
$$

where $[E t O H]_{\max }$ is the maximum ethanol concentration, and [Monosaccharide $]_{i n i}$ is the concentration of glucose and galactose $(\mathrm{g} / \mathrm{l})$ at the onset of fermentation.

\section{Analytical Methods}

The glucose, galactose, HMF, and ethanol concentrations in the samples were determined by HPLC (Agilent 1100 Series; Agilent Inc., USA) with a refractive index detector. An Aminex HPX-87H column $(300 \times 7.8 \mathrm{~mm}$; Bio-Rad, USA) was used with filtered and degassed $5 \mathrm{mM}$ sulfuric acid at an elution rate of $0.6 \mathrm{ml} / \mathrm{min}$. Before analysis, aqueous samples were centrifuged at $8,000 \times g$ for $12 \mathrm{~min}$, and the supernatant was filtered through a $0.2 \mu \mathrm{m}$ syringe filter.

\section{Statistical Analysis}

Optimal pretreatment conditions were determined with the RSM using SAS ver. 9.4 (SAS Institute, USA) $[14,15]$.

\section{Results}

\section{Thermal Acid Hydrolysis}

Seaweed samples were subjected to thermal acid hydrolysis. The reaction temperature and $\mathrm{HNO}_{3}$ concentration with various thermal hydrolysis periods were plotted based on a three-dimensional response surface method. The monosaccharide concentration was increased with the acid concentration, reaction time, and slurry concentration. Variables including the hydrolysis temperature $\left(X_{1}\right), \mathrm{NHO}_{3}$ concentration $\left(X_{2}\right)$, and reaction time $\left(X_{3}\right)$ were assessed using $12 \%(\mathrm{w} / \mathrm{v})$ G. verrucosa slurry, and the results are summarized in Table 1. The regression coefficients were calculated, and the predictive response model equation for $Y$ as the pretreatment efficiency $\left(E_{p}\right)$ was expressed as Eq. (7):

$$
\begin{aligned}
\mathrm{Y}= & -128.453973+20.677701 \mathrm{X}_{1}+0.12802 \mathrm{X}_{2}+0.355691 \mathrm{X}_{3}-0.000881 \mathrm{X}_{1} \mathrm{X}_{2}+0.000837 \mathrm{X}_{1} \mathrm{X}_{3} \\
& -0.000026761 \mathrm{X}_{2} \mathrm{X}_{3}-0.717684 X_{1} X_{1}-0.000108 \mathrm{X}_{2} \mathrm{X}_{2}-0.001863 \mathrm{X}_{3} \mathrm{X}_{3}
\end{aligned}
$$

Based on the high value of $\mathrm{R}_{2}=0.9308$, the regression was statistically significant, indicating that thermal acid hydrolysis had a significant effect on monosaccharide release from $G$. verrucosa. The results obtained through this equation are shown in Fig. 1. The red-colored part indicates the optimal conditions for thermal acid hydrolysis to produce $57.4 \mathrm{~g} / \mathrm{l}$ monosaccharides. Green and blue areas in Fig. 1. indicate lower pretreatment efficiency. When $500 \mathrm{mM}$ acid, $90 \mathrm{~min}$ of treatment time, and 12\% slurry were used, the maximum yield of monosaccharides was 


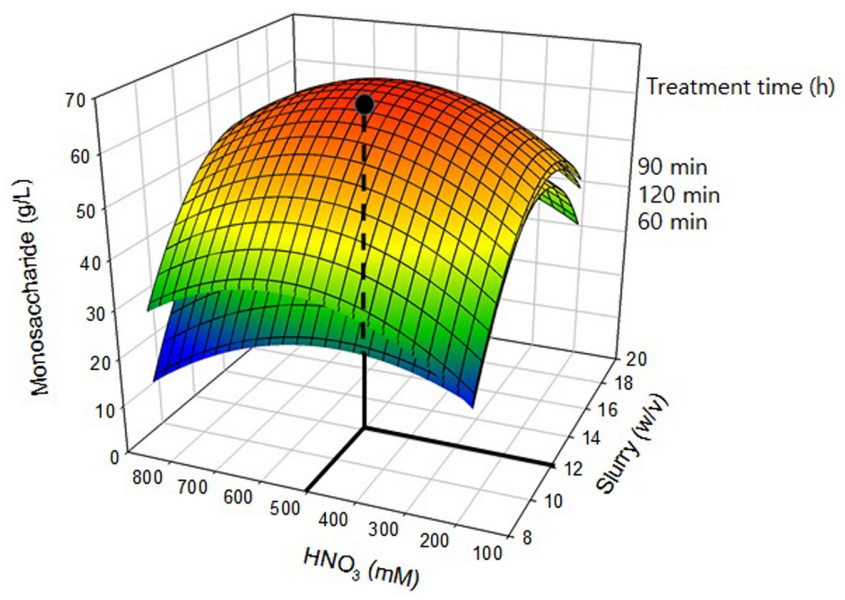

Fig. 1. Response surface curve showing the combined effect of $\mathrm{HNO}_{3}$ concentration and slurry content on monosaccharide production.

obtained as shown in Fig. 1. The production of inhibitors such as formic acid, levulinic acid, and HMF occurred during acid hydrolysis. Therefore, the optimal pretreatment conditions for obtaining monosaccharides were $12 \%$ (w/v) G. verrucosa slurry and $500 \mathrm{mmol} / 1 \mathrm{HNO}_{3}$ at $121^{\circ} \mathrm{C}$ for $90 \mathrm{~min}$.

\section{Enzymatic Saccharification}

Enzymatic saccharification was performed to obtain glucose after thermal acid hydrolysis [16]. Cellulase is an effective enzyme for obtaining glucose from cellulose. As shown in Fig. 2, a synergistic effect was achieved with multiple enzymes (Cellic C-Tec 2 and Celluclast $1.5 \mathrm{~L}$ ), and saccharification was the highest compared with that of single enzyme treatments using Cellic C-Tec 2 or Celluclast $1.5 \mathrm{~L}$. Therefore, enzymatic saccharification was carried out using a mixture of Cellic C-Tec 2 and Celluclast $1.5 \mathrm{~L}$ for $72 \mathrm{~h}$. When Cellic C-Tec 2 was used as the enzyme for hydrolysis, $60.2 \mathrm{~g} / \mathrm{l}$ monosaccharides were obtained, and when Celluclast $1.5 \mathrm{~L}$ was used, $57.8 \mathrm{~g} / \mathrm{l}$ monosaccharides were obtained. When a mixture of the enzymes (Cellic C-Tec 2 and Celluclast 1.5L) was used, $61.0 \mathrm{~g} / \mathrm{l}$ monosaccharides were obtained.

\section{Removal of HMF}

HMF is formed by the dehydration of monosaccharides and is known as an inhibitor of ethanol production. HMF was removed using activated carbon [17]. HMF removal was performed using $2 \%$ activated carbon for $2 \mathrm{~min}$ at a reaction temperature of $50^{\circ} \mathrm{C}$ with a rotational speed of $150 \mathrm{rpm}$ [5]. The reaction was carried out under optimal conditions. Therefore, there was no loss of monosaccharides, and the amount of HMF was decreased from $5.1 \mathrm{~g} / \mathrm{l}$ to $0.8 \mathrm{~g} / \mathrm{l}$ as shown in Fig. 3 .

\section{Fermentation}

Three yeast strains, S. cerevisiae, C. lusitaniae, and K. marxianus, were used for fermentation [18]. Each fermentation was carried out with the addition of wild-type yeasts and yeasts adapted to high galactose

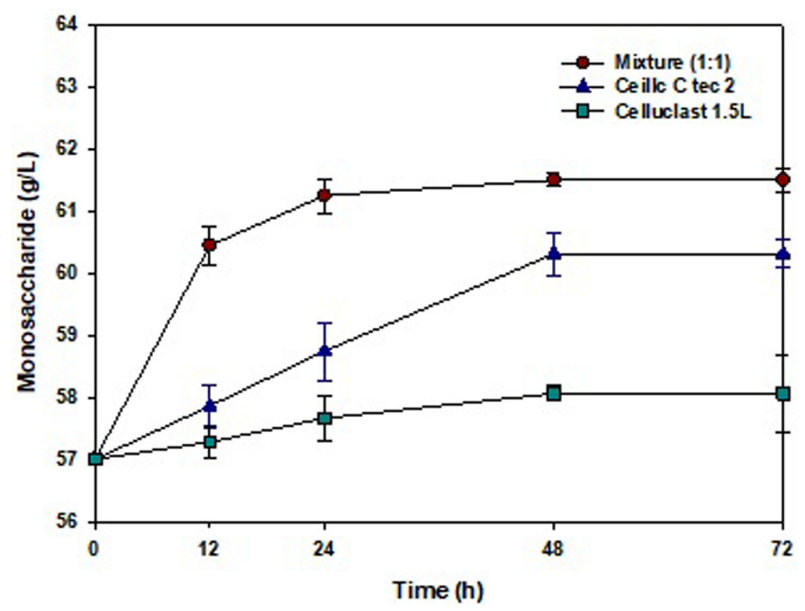

Fig. 2. Enzymatic saccharification of $G$. verrucosa hydrolysate using a mixture of Celluclast $1.5 \mathrm{~L}$ and Cellic C-Tec2 (1:1 ratio; $16 \mathrm{U} / \mathrm{ml})$, Cellic C-Tec2, or Celluclast $1.5 \mathrm{~L}$ (16 units $/ \mathrm{ml})$. 


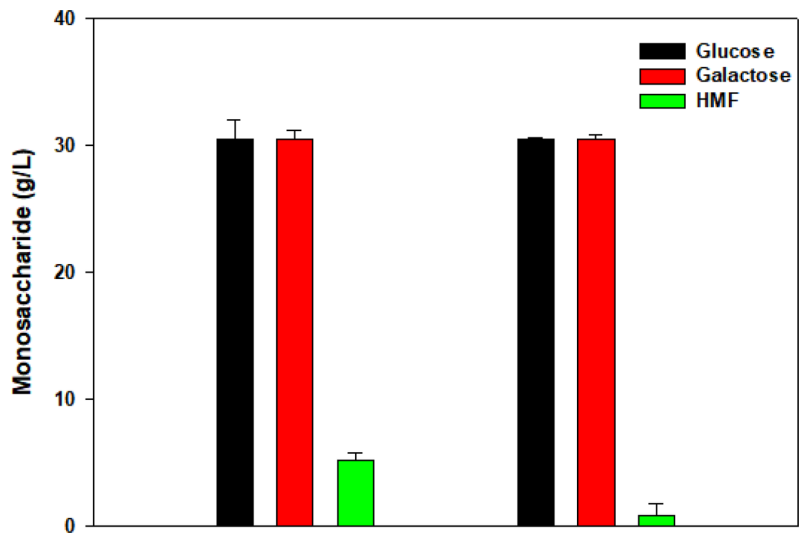

Fig. 3. Effect of activated carbon with $2 \mathrm{~min}$ of adsorption time on HMF and monosaccharide concentrations in a shaking incubator at $150 \mathrm{rpm}$ and $50^{\circ} \mathrm{C}$ (HMF removal). The bars represent the mean \pm standard deviations of glucose, galactose, and HMF following thermal acid hydrolysis.

concentrations (adaptive evolution). Ethanol was produced over $96 \mathrm{~h}$ of fermentation as shown in Fig. 4-6. When wild-type S. cerevisiae was used, ethanol production reached $19.0 \mathrm{~g} / \mathrm{l}$ as shown in Fig. 4A. However, S. cerevisiae adapted to high concentrations of galactose produced $23.5 \mathrm{~g} / \mathrm{l}$ ethanol as shown in Fig. 4B. The ethanol yield coefficient $\left(\mathrm{Y}_{\mathrm{EtOH}}\right)$ was 0.39 using adaptively evolved S. cerevisiae and 0.31 using wild-type S. cerevisiae. Therefore, the ethanol yield was higher using adaptively evolved S. cerevisiae instead of wild-type $S$. cerevisiae.

Ethanol production using wild-type C. lusitaniae was $26.0 \mathrm{~g} / 1\left(\mathrm{Y}_{\mathrm{EtOH}}=0.43\right)$ and using adaptively evolved C. lusitaniae was $26.7 \mathrm{~g} / \mathrm{l}\left(\mathrm{Y}_{\mathrm{EtOH}}=0.44\right)$ as shown in Figs. 5A and 5B, respectively. The use of C. lusitaniae adapted to high concentrations of galactose did not increase the ethanol yield coefficient significantly. This is because C. lusitaniae can consume galactose even if it is not adapted to high concentrations of galactose. However,

A

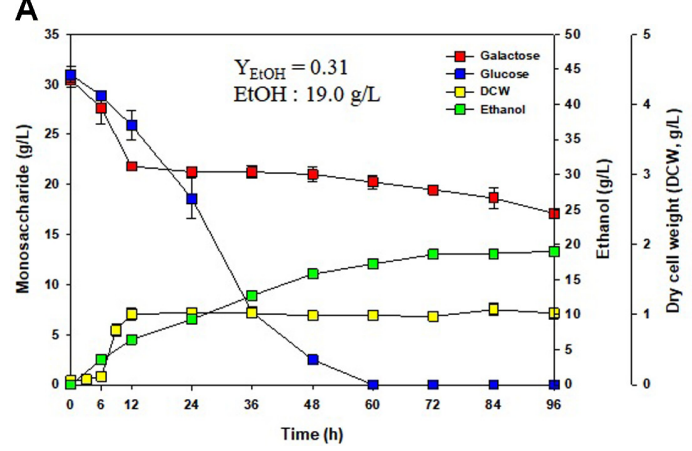

B

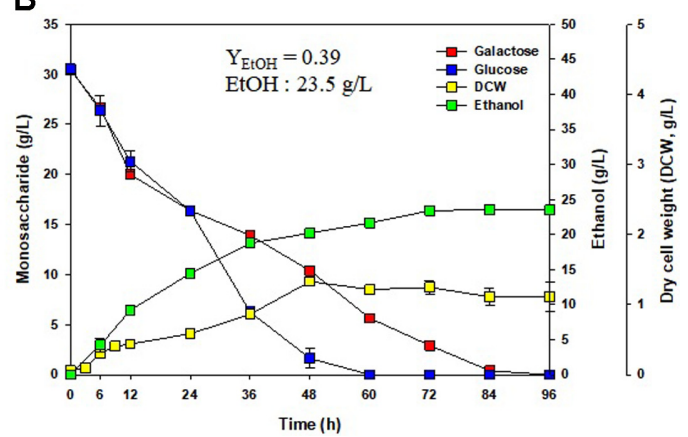

Fig. 4. Ethanol production with G. verrucosa as substrate using Saccharomyces cerevisiae for fermentation. (A) Wild-type S. cerevisiae and (B) S. cerevisiae adapted to high concentrations of galactose.

A

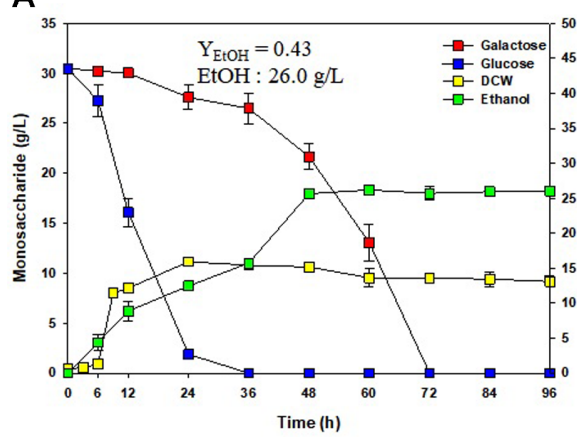

B

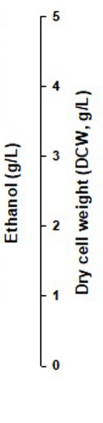

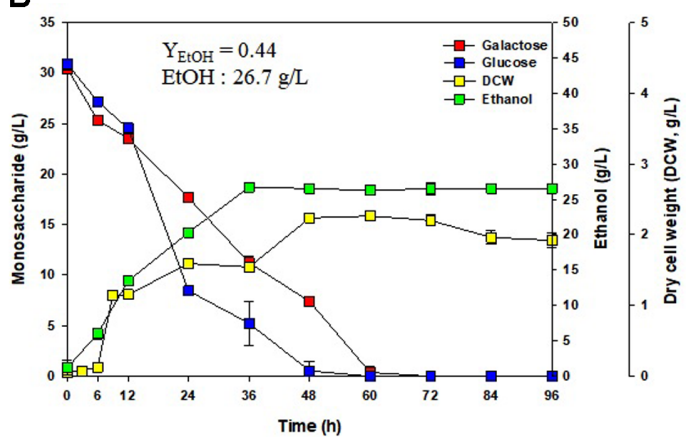

Fig. 5. Ethanol production with G. verrucosa as substrate using Candida lusitaniae for fermentation. (A) Wild-type C. lusitaniae and (B) C. lusitaniae adapted to high concentrations of galactose. 
A

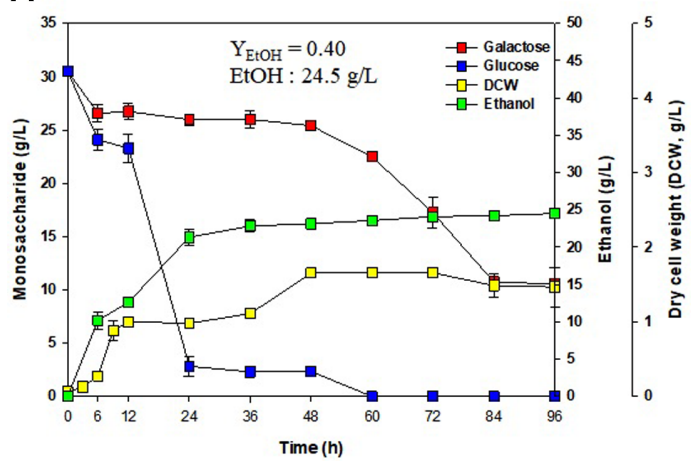

B

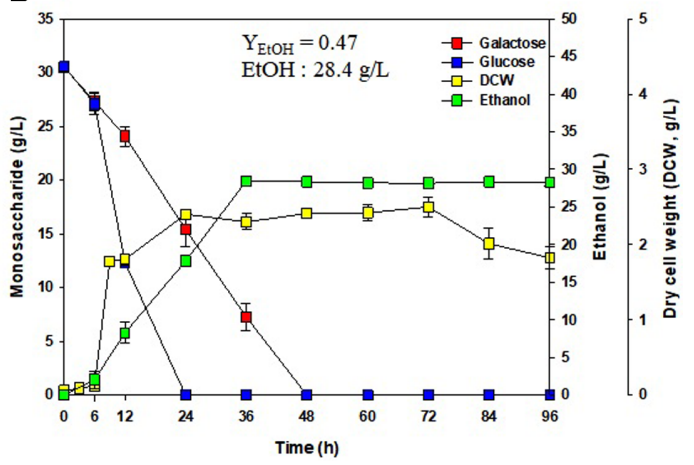

Fig. 6. Ethanol production with G. verrucosa as substrate using Kluyveromyces marxianus for fermentation.

adaptive evolution could reduce the time required to consume galactose. The diauxic production of ethanol was observed with wild-type $C$. lusitaniae, which exhibited a distinct pattern in the shift from glucose to galactose consumption. After complete glucose exhaustion, galactose was consumed by C. lusitaniae. Fig. 5A shows the complete consumption of galactose in $72 \mathrm{~h}$ using wild-type C. lusitaniae, and Fig. 5B shows the complete consumption of galactose in $60 \mathrm{~h}$ using adaptively evolved C. lusitaniae.

The outcome following the use of K. marxianus was similar to that following the use of S. cerevisiae. Wild-type K. marxianus produced $24.5 \mathrm{~g} / \mathrm{l}$ ethanol $\left(\mathrm{Y}_{\mathrm{EtOH}}=0.40\right)$, and adaptively evolved $K$. marxianus produced $28.4 \mathrm{~g} / \mathrm{l}$ ethanol $\left(\mathrm{Y}_{\mathrm{EtOH}}=0.47\right)$, as shown in Figs. 6A and 6B, respectively. Among the yeasts used in the study, K. marxianus produced the highest concentration of ethanol with the highest ethanol yield coefficient $\left(\mathrm{Y}_{\mathrm{EtOH}}=0.47\right)$. In addition, $K$. marxianus adapted to high concentrations of galactose produced the maximum ethanol concentration in $36 \mathrm{~h}$.

\section{Discussion}

The use of $\mathrm{HNO}_{3}$ produced monosaccharides in a short reaction time and showed a high saccharification efficiency compared with the efficiency using other acids such as sulfuric acid or hydrochloric acid [18, 19]. In this study, pretreatment with $\mathrm{HNO}_{3}$ resulted in a high monosaccharide production efficiency as shown in Fig. 1 [5]. The duration of heat treatment $(60,90$, and $120 \mathrm{~min})$ at $121^{\circ} \mathrm{C}$ was evaluated. Monosaccharide production for 90 and $120 \mathrm{~min}$ showed similar results. Therefore, $90 \mathrm{~min}$ was selected as the optimal treatment time, which was determined based on statistical evaluation using SAS software.

Monosaccharides could be obtained by thermal acid hydrolysis using $\mathrm{HNO}_{3}$. The optimal conditions for thermal acid hydrolysis pretreatment were $12 \%$ slurry and $500 \mathrm{mmol} / \mathrm{L} \mathrm{HNO}_{3}$ for $90 \mathrm{~min}$ at $121^{\circ} \mathrm{C}$. Pretreatment with $G$. verrucosa produced $57 \mathrm{~g} / \mathrm{l}$ monosaccharides. The optimal conditions were used for obtaining a high concentration of monosaccharides.

A mixture (1:1 ratio) of Celluclast 1.5 L and Cellic C-Tec 2 was used in saccharification to efficiently produce glucose. The use of the two enzymes together had a synergistic effect on cellulose degradation [21]. Through the processes of thermal acid hydrolysis and enzymatic saccharification, $76 \%$ of monosaccharides were obtained from the carbohydrates of G. verrucosa.

A lag phase could be observed when the medium contains more than one sugar. This phenomenon, known as the diauxic production of ethanol, is caused by a shift in metabolic pathways with the change from glucose to galactose consumption as shown in Fig. 5A. After glucose exhaustion, the cells were adapted to utilize galactose. Glucose is more readily metabolized than galactose, and the presence of more readily available sugars such as glucose suppresses the synthesis of enzymes required for the metabolism of secondary sugars such as galactose. The red seaweed G. verrucosa contains glucose and galactose. Therefore, galactose was consumed as shown in Figs. 4B, 5B, and 6B.

For fermentation, three yeasts (S. cerevisiae, C. lusitaniae, and K. marxianus) were used to produce ethanol. Yeasts prefer glucose to galactose, and they have evolved to consume glucose rather than galactose. Wild-type yeasts consume minimal amounts of galactose. Therefore, the adaptive evolution of yeasts to high concentrations of galactose was performed, and the ethanol yield coefficient was improved using yeasts adapted to high concentrations of galactose. Ethanol production was increased using the adaptively evolved yeasts compared with the wild-type yeasts. Wild-type $S$. cerevisiae produced $19.0 \mathrm{~g} / \mathrm{l}$ ethanol, which was increased to $23.5 \mathrm{~g} / \mathrm{l}$ using S. cerevisiae adapted to high concentrations of galactose. Ethanol yield of $27 \%$ increase was obtained by the adaptive evolution with S. cerevisiae. C. lusitaniae adapted to high concentrations of galactose was used to increase ethanol production from $26.0 \mathrm{~g} / \mathrm{l}$ to $26.7 \mathrm{~g} / \mathrm{l}$. Ethanol production by C. lusitaniae adapted to high concentration of galactose showed $2 \%$ increase comparing to that of wild-type strain. A significant increase in ethanol production was not observed for C. lusitaniae considering the active consumption of galactose by both wild-type C. lusitaniae and C. lusitaniae adapted to high concentrations of galactose. Wild-type K. marxianus produced $24.5 \mathrm{~g} / \mathrm{l}$ ethanol, and ethanol production was increased to $28.4 \mathrm{~g} / \mathrm{l}$ using K. marxianus adapted to high concentrations of galactose. When adaptive evolution-type K. marxianus was used, $16 \%$ more ethanol was produced than that of the wild-type 
K. marxianus. In contrast to $C$. lusitaniae, $K$. marxianus showed a higher ethanol production efficiency due to efficient galactose consumption following adaptive evolution. The ethanol yield coefficient was 0.40 using wildtype $K$. marxianus, whereas the ethanol yield coefficient was the highest at 0.47 using adaptive evolution-type $K$. marxianus. S. cerevisiae has been improved with the best adaptation effect. Adaptive evolution-type S. cerevisiae showed 27\% higher ethanol production than wild-type S. cerevisiae. Among the three yeast strains, the highest ethanol yield coefficient was obtained from fermentation using galactose adaptive evolution-type $K$. marxianus.

\section{Acknowledgments}

This work was supported by the National Research Foundation of Korea (NRF), the Ministry of Education (2019R1F1A1041288) and by a Center for Women In Science, Engineering and Technology (WISET) grant funded by the Ministry of Science and ICT (MSIT) under the team research program for female engineering students.

\section{Conflict of Interest}

The authors have no financial conflicts of interest to declare.

\section{References}

1. Kumar S, Gupta R, Kumar G, Kuhad D, Chander R. 2013. Bioethanol production from Gracilaria verrucosa, a red alga, in a biorefinery approach. Bioresour. Technol. 135: 150-156.

2. Binod P, Gnansounou E, Sindhu R, Pandey A. 2019. Enzymes for second generation biofuels: recent developments and future perspectives. Bioresour. Technol. Rep. 5: 317-325.

3. Melo MRS, Feitosa JPA, Freitas ALP, Paula RCM De. 2002. Isolation and characterization of soluble sulfated polysaccharide from the red seaweed Gracilaria cornea. Carbohydr. Polym. 49: 491-498.

4. Ramachandra T V, Hebbale D. 2020. Bioethanol from macroalgae: Prospects and challenges. Renew. Sust. Energ. Rev. $117: 109479$.

5. Sukwong P, Sunwoo IY, Lee MJ, Ra CH, Jeong GT, Kim SK. 2018. Application of the severity factor and HMF removal of red macroalgae Gracilaria verrucosa to production of bioethanol by Pichia stipitis and Kluyveromyces marxianus with adaptive evolution. Appl. Biochem. Biotechnol. 187: 1312-1327.

6. Sunwoo IY, Ra CH, Jeong GT, Kim SK. 2016. Evaluation of ethanol production and bioadsorption of heavy metals by various red seaweeds. Bioprocess Biosyst. Eng. 39: 915-923.

7. Ra CH, Jung JH, Sunwoo IY, Kang CH, Jeong GT, Kim SK. 2015. Detoxification of Eucheuma spinosum hydrolysates with activated carbon for ethanol production by the salt-tolerant yeast Candida tropicalis. J. Microbiol. Biotechnol. 25: 856-862.

8. Dahnum D, Tasum SO, Triwahyuni E, Nurdin M, Abimanyu H. 2015. Comparison of SHF and SSF processes using enzyme and dry yeast for optimization of bioethanol production from empty fruit bunch. Energy Procedia 68: 107-116.

9. El Harchi M, Fakihi Kachkach FZ, El Mtili N. 2018. Optimization of thermal acid hydrolysis for bioethanol production from Ulva rigida with yeast Pachysolen tannophilus. S. Afr. J. Bot. 115: 161-169.

10. Sunwoo IY, Nguyen TH, Ra CH, Jeong GT, Kim SK. 2018. Acetone-Butanol-Ethanol production from waste seaweed collected from Gwangalli beach, Busan, Korea, based on pH-controlled and sequential fermentation using two strains. Appl. Biochem. Biotechnol. 185: $1075-1087$.

11. Lan TQ, Lou H, Zhu JY. 2013. Enzymatic saccharification of lignocelluloses should be conducted at elevated pH 5.2-6.2. Bioenerg. Res. 6: $476-485$.

12. Jol CN, Neiss TG, Penninkhof B, De Ruiter GA. 1999. A novel high-performance anion-exchange chromatographic method for the analysis of carrageenans and agars containing 3,6-anhydrogalactose. Anal. Biochem. 268: 213-222.

13. Nguyen TH, Ra CH, Sunwoo IY, Sukwong P, Jeong GT, Kim SK. 2017. Bioethanol production from soybean residue via separate hydrolysis and fermentation. Appl. Biochem. Biotechnol. 184: 513-523.

14. Ra CH, Kim SK. 2013. Optimization of pretreatment conditions and use of a two-stage fermentation process for the production of ethanol from seaweed, Saccharina japonica. Biotechnol. Bioprocess Eng. 18: 715-720.

15. Yoo CG, Lee CW, Kim TH. 2011. Optimization of two-stage fractionation process for lignocellulosic biomass using response surface methodology (RSM). Biomass Bioeneergy 35: 4901-4909.

16. Farkas C, Rezessy-Szabó JM, Gupta VK, Truong DH, Friedrich L, Friedrich J, et al. 2019. Microbial saccharification of wheat bran for bioethanol fermentation. J. Clean Prod. 240: 118269.

17. Kumar V, Yadav SK, Kumar J, Ahluwalia V. 2020. A critical review on current strategies and trends employed for removal of inhibitors and toxic materials generated during biomass pretreatment. Bioresour. Technol. 299: 122633

18. Demiray E, Ertuğrul Karatay S, Dönmez G. 2019. Efficient bioethanol production from pomegranate peels by newly isolated Kluyveromyces marxianus. Energy Sources, Part A: Recovery, Utilization and Environmental Effects 42: 709-718.

19. Vázquez BC, Roa-morales G, Natividad R, Balderas-hernández P, Saucedo-luna J. 2006. Thermal hydrolysis of orange peel and its fermentation with alginate beads to produce ethanol. BioResources 12: 2955-2964.

20. Kim I, Lee B, Park JY, Choi SA, Han JI. 2014. Effect of nitric acid on pretreatment and fermentation for enhancing ethanol production of rice straw. Carbohydr. Polym. 99: 563-567.

21. Resch MG, Donohoe BS, Baker JO, Decker SR, Beck EA, Beckham GT, et al. 2013. Fungal cellulases and complexed cellulosomal enzymes exhibit synergistic mechanisms in cellulose deconstruction. Energy Environ. Sci. 6: 1858-1867.

22. Stévant P, Rebours C, Chapman A. 2017. Seaweed aquaculture in Norway: recent industrial developments and future perspectives. Aquac. Int. 25: 1373-1390. 